\title{
ISOLASI DAN IDENTIFIKASI Staphylococcus sp. DARI UDARA DI RUANGAN BER-AC GEDUNG ANALIS KESEHATAN
}

\author{
Hamtini $^{1}$,Ira Nuraeni ${ }^{1}$ \\ ${ }^{1}$ Jurusan Analis Kesehatan Politeknik Kesehatan Kemenkes Banten, Tangerang \\ Korespondensi: hamtini.bio05@gmail.com
}

\begin{abstract}
Poor indoor air quality can cause serious health problems, poor air quality can be affected by the presence of microorganisms, one of which is bacteria. The purpose of this study was to determine the presence of Staphylococcus sp. bacteria in the office of the Health Analyst Department office with air conditioning. Bacterial isolation was obtained from air samples in air-conditioned office rooms with descriptive research methods, namely getting a picture of the presence of Staphylococcus sp. Isolation was carried out using differential selective media namely Mannitol Salt Agar, then identification was done with Gram staining, after that identification was continued with catalase test and coagulase test. The results of identification with Gram staining were obtained 119 bacterial isolates were Gram positive bacteria with cocci shape. After the Gram staining of the isolates was carried out by catalase test and there were 113 positive isolates of catalase, then proceed with the coagulase test, the results of the coagulase test found that 20 bacterial isolates from the coagulase test showed positive results. From the results and discussion it can be concluded that there is the presence of Staphylococcus sp. which is an air contaminant bacterium in an air-conditioned room in the office of the Banten Health Polytechnic Health Analyst department and is likely to cause health problems for humans
\end{abstract}

\section{Keywords: Staphylococcus sp, Air, air-conditioned room}

\begin{abstract}
ABSTRAK
Kualitas udara dalam ruangan yang buruk dapat menyebabkan gangguan kesehatan yang serius dan fatal, kualitas udara yang buruk dapat dipengaruhi oleh adanya mikrooganisme salah satunya adalah bakteri. Tujuan dari penelitian ini adalahuntuk mengetahui keberadaan bakteri Staphylococcus sp. di ruangan kantor Jurusan Analis Kesehatan yang ber AC. Isolasi bakteri didapatkan dari sampel udara di ruangan kantor ber- AC dengan metode penelitian deskriptif yaitu mendapatkan gambaran tentang keberadaan bakteri Staphylococcus sp. Isolasi dilakukan dengan menggunakan media selektif diferensial yaitu Mannitol Salt Agar, kemudian identifikasi di lakukan dengan pewarnaan Gram, setelah itu identifikasi di lanjutkan dengan Uji Katalase dan Uji Koagulase. Hasil identifikasi dengan pewarnaan Gram di dapatkan 119 kisolat bakteri merupakan bakteri Gram positif dengan bentuk kokus. Setelah di lakukan pewarnaan Gram isolat-isolat
\end{abstract}


tersebut di lanjutkan dengan uji katalase dan terdapat 113 isolat positif katalase, kemudian di lanjutkan dengan uji koagulase, hasil uji koagulase di dapatkan 20 isolat bakteri hasil uji koagulase menunjukkan hasil positif. Dari hasil dan pembahasan dapat disimpulkan terdapat keberadaan bakteri Staphylococcus sp. yang merupakan bakteri kontaminan udara di dalam ruangan ber-AC di ruang kantor jurusan Analis Kesehatan Politeknik Kesehatan Banten dan kemungkinan besar dapat penyebabkan masalah kesehatan bagi manusia

\section{Kata Kunci: Staphylococcus sp, Udara, Ruangan ber-AC}

\section{PENDAHULUAN}

Udara merupakan suatu komponen yang paling utama untuk mempertahankan kehidupan, karena metabolisme dalam tubuh suatu makhluk hidup tidak mungkin bisa terjadi tanpa adanya oksigen dalam udara.Peningkatan konsentrasi zatzat di dalam udara tersebut dapat disebabkan oleh aktivitas manusia (Fitria, 2008).Penggunaan air conditioner(AC) sebagai alternatif untuk mengganti ventilasi alami dapat meningkatkan kenyamanan dan produktivitas kerja, namun AC yang jarang dibersihkan akan menjadi tempat nyaman bagi mikroorganisme untuk berkembangbiak (Prasasti, 2005). Karena banyaknya efek yang disebabkan oleh kualitas udara yang buruk maka Pemerintah Indonesia telah mengatur persyaratan kualitas udara dalan ruang perkantoran yaitu dengan Keputusan Menteri $\begin{array}{lll}\text { Kesehatan } & \text { RI }\end{array}$ 1405/MENKES/SK/XI/2002 dalam keputusan tersebut dinyatakan bahwa Angka kuman kurang dari 770 koloni/m3 udara, bebas kuman patogen (Kemenkes 2002).

Hasil penelitian pada kualitas mikrobiologi udara dalam ruangan perpustakaan di sebuah Universitas di temukan bakteri Micrococcus sp., Staphylococcus aureus, Streptococcus pyogenes, Bacillus sp., dan Neisseria sp. (Hayleeyesus, 2014). Staphylococcus sp. merupakan mikroflora normal dalam keadaan normal terdapat di kulit, saluran pernafasan atas kulit saluran cerna tetapi Staphylococcussp. juga merupakan penyebab penting terjadinya penyakit pada manusia 
Hamtini,dkk. Isolasi dan Indentifikasi Staphylococcus sp.

dalam keadaan yang tidak menguntungkan

(Jawetz,

2008).Berdasarkan uraian latar

belakang tersebut sehingga perlu

dilakukan penelitian tentang "Isolasi

dan identifikasi Staphylococcus sp.

dari udara di ruangan ber-Ac Gedung

Analis Kesehatan.”

\section{METODE}

Desain dalam penelitian ini adalah secara deskriptif dengan menggunakan uji laboratorium. Penelitian ini dilaksanakan pada bulan Juli-November 2017 di laboratorium Mikrobiologi Jurusan Analis Kesehatan.Bahan-bahan yang digunakan dalam penelitian media, MSA (Mannitol salt agar), Aquades, Reagan Pewarnaan Gram, $\mathrm{NaCl}$ fisiologis, spiritus, alkohol $70 \%$. Peralatan yang digunakan antara lain adalah laminar air flow, ose, cawan petri, tabung reaksi, rak tabung, bunsen.

Media di biarkan terbuka di dalam ruangan-ruangan Gedung Analis Kesehatan selama 30 menit pada titik-titik yang telah di tentukan, kemudian di inkubasi selama 24 jam dengan suhu $37^{\circ}$ c.Identifikasi bakteri Staphylococcus sp. yang di dapat hasil isolasi dengan Pewarnaan Gram, Uji Katalase, dan Uji Koagulase.Data hasil penelitian ini disajikan secara deskriptif dalam bentuk tabel dan gambar.

\section{HASIL DAN PEMBAHASAN}

Pengambilan sampel udara di ruangan ber AC gedung kantor Analis Kesehatan terdiri dari 7 ruangan dilakukan pada tiga waktu yaitu pagi jam 07.30-08.00 WIB, siang jam 12.30-13.00 WIB, dan sore hari jam 17.30-18.00 WIB menggunakan media Mannitol Salt Agar yang dibiarkan terbuka selama 30 menit, didapatkan jumlah koloni bakteri sebagai berikut.

Tabel 1. Jumlah koloni bakteri hasil isolasi pada ruangan ber AC di gedung kantor Analis Kesehatan

\begin{tabular}{lcccc}
\hline Ruangan* & \multicolumn{3}{c}{ Waktu } & Jumlah \\
\cline { 2 - 4 } & Pagi & Siang & Sore & koloni/CFU \\
\hline Ruangan A & 18 & 3 & 7 & 28 \\
\hline Ruangan B & 8 & 2 & 4 & 14 \\
\hline Ruangan C & - & 31 & - & 31 \\
\hline Ruangan D & 10 & 8 & 10 & 28 \\
\hline Ruangan E & 20 & 2 & 4 & 26 \\
\hline Ruangan F & 17 & 3 & 10 & 30 \\
\hline Ruangan G & 6 & - & 2 & 8 \\
\hline *Keterangan: A: Dosen 1, B: Dosen 2, C: \\
Arsip, D: Akademik, E: Seketaris Jurusan, \\
F: Instruktur, G: Keuangan \\
Identifikasi dilakukan dengan \\
pewarnaan Gram untuk mengetahui
\end{tabular}

Jurnal Medikes, Volume 5, Edisi 2, November 2018 
isolat bakteri yang di dapat merupakan bakteri Gram positif berbentuk kokus.

Tabel 2. Hasil identifikasi isolat dengan pewarnaan Gram positif dan berbentuk kokus

\begin{tabular}{cc}
\hline Ruangan* & $\begin{array}{c}\text { Jumlah } \\
\text { isolat }\end{array}$ \\
\hline Ruangan A & 19 \\
Ruangan B & 9 \\
Ruangan C & 26 \\
Ruangan D & 21 \\
Ruangan E & 20 \\
Ruangan F & 17 \\
Ruangan G & 6 \\
\hline
\end{tabular}

*Keterangan: A: Dosen 1, B: Dosen 2, C: Arsip, D: Akademik, E: Seketaris Jurusan, F: Instruktur, G: Keuangan

Tabel 3. Hasil Uji koagulase

\begin{tabular}{ccc}
\hline Ruangan & $\begin{array}{c}\text { Jumlah } \\
\text { isolat }\end{array}$ & Koagulase \\
\hline Ruangan A & 5 & + \\
Ruangan B & 2 & + \\
Ruangan C & 1 & + \\
Ruangan D & 6 & + \\
Ruangan E & 1 & + \\
Ruangan F & 5 & + \\
\hline
\end{tabular}

Pada penelitian ini di lakukan isolasi dan identifikasi Staphylococcus sp. pada ruangan kantor ber AC Jurusan Analis Kesehatan Poltekkes Banten.Pada penelitian ini dilakukan isolasi dan identifikasi Staphylococcus sp. karena beberapa kondisi bakteri ini dapat menimbulkan masalah kesehatan pada manusia.
BerdasarkanTabel 1 terlihat bahwa jumlah koloni bakteri dibeberapa ruangan lebih banyak ditemukan diwaktu pengambilan sampel pada pagi hari, hal ini dapat disebabkan karna pada pagi hari aktivitas banyak di lakukan oleh para pekerja mulai dari menyiapkan segala keperluan pekerjaan, melakukan aktivitas berbicara dan sarapan sehingga kemungkinan besar menyebabkan intensitas jumlah koloni bakteri yang ditemukan lebih banyak. Namun sebaliknya terjadi pada Ruangan C dimana pada pengambilan di pagi hari dan sore hari tidak ditemukan koloni bakteri tetapi jumlah koloni mengalami peningkatan pada siang hari, hal ini kemungkinan dapat disebabkan karena jumlah pekerja yang menempati ruangan tersebut hanya berjumlah 1 orang, sehingga aktivitas yang dilakukan lebih sedikit. Menurut Lazuardi W, 2016 kualitas dan kenyamanan udara akan sangat berpengaruh terhadap kondisi kesehatan baik lingkungan maupun maupun manusia, terutama untuk udara dalam ruangan. 
Identifikasi dilakukan untuk mengetahui spesies dari koloni bakteri yang tumbuh pada media MSA yaitu dengan dilakukan pewarnaan Gram.Staphylococcus sp. merupakan bakteri kokus Gram positif berbentuk kokus yang merupakan flora normal pada manusia.Bakteri ini juga dapat ditemukan pada lingkungan yang kontak dengan manusia dan udara.Sumber penyebab polusi udara dalam ruangan antara lain yang berhubungan dengan bangunan itu sendiri, perlengkapan dalam bangunan (karpet, AC, dan sebagainya), kondisi bangunan, suhu, kelembaban, pertukaran udara, dan hal-hal yang berhubungan dengan perilaku orang-orang yang berada di dalam ruangan, misalnya merokok (Fitria, 2008)

Berdasarkan Tabel 2. dapat dilihat bahwa hasil pewarnaan Gram terdapat 113 koloni bakteri yang merupakan bakteri Gram positif dengan bentuk kokus, hal ini dapat menjadi indikasi awal bahwa koloni yang di dapat merupakan Staphylococcus sp. sehingga isolat bakteri tersebut di lanjutkan identifikasi berikutnya dengan uji katalase, Koloni bakteri yang memfermentasikan mannitol terlihat dari warna kuning pada media MSA di lanjutkan untuk uji koagulase dengan reagen plasma di tambah $\mathrm{Na}$ Citrat hasil positif di tunjukkan dengan terbentuk butiran pasir. Uji Koagulase digunakan untuk membedakan bakteri Staphylococcus saprophyticus dengan

Staphylococcus aureus.

\section{Staphylococcus aureus} merupakan bakteri flora normal tetapi merupakan bakteri yang paling sering menimbulkan penyakit dengan hasil koagulase positif produksi koagulase dianggap sama dengan memiliki potensi menjadi patogen invasif (Jawetz, 2014).Sebagai suatu upaya untuk memperoleh kenyamanan bagi para penghuni yang mendiami suatu ruangan di dalam gedung atau bangunan, maka perencanaan ventilasi dan pengkondisian udara merupakan salah satu syarat utama yang wajib dipenuhi (Lazuardi W, 2016). 


\section{SIMPULAN}

Berdasarkan hasil dan pembahasan yang telah di buat dapat disimpulkan bahwa terdapat keberadaan bakteri Staphylococcus sp. di dalam ruangan ber-AC kantor Analis Kesehatan Politeknik Kesehatan Banten dengan ditemukannya 20 koloni bakteri Gram positif dengan bentuk kokus, uji katalase dan koagulasenya positif dan memfermentasi mannitol.

\section{DAFTAR PUSTAKA}

Fitria L.,Wulandari RA, Erma Hermawati E, Susanna D. 2008. Kualitas udara dalam ruang perpustakaan universitas " $\mathrm{x}$ " ditinjau dari kualitas biologi, fisik dan kimia. Makara, Kesehatan 12(2): 77-83.

Hayleeyesus SM, Manaye AM. 2014. Microbiological quality of indoor air in Universty Libraries. Asian Pac J Biomed. 4 (Suppl 1):S312S317.doi:12980/APJTB.4.2014 C.807.

Jawetz M, Adelberg, ED. 2008.

Mikrobiologi Kedokteran.

Yogyakarta: EGC.

Keputusan Menteri Kesehatan RI No.1405/MENKES/SK/XI/2002 tentang Persyaratan Kesehatan
Lingkungan Kerja Perkantoran dan Industri.

Lazuardi W. 2016. Pemantauan Kondisi kualitas air dan udara dalam ruangan di gedung Andi Hakim Nasoetion Institut Pertanian Bogor. [Skripsi]. IPB

Prasasti CI., Mukono J, Sudarmaji. 2005. Pengaruh Kualitas Udara dalam ruangan ber-AC terhadap gangguan kesehatan.Jurnal Kesehatan Lingkungan. 1(2).

Prasasti CI., Sudarmaji, Adriyani R. 2013. Kualitas udara dalam ruang kelas berAC dan keluhan kesehatan siswa.J Kesehatan Lingkungan. 7(1):14-20 